\title{
Homenagem a João Paisana na abertura oficial do Ano Lectivo de Filosofia de 2001/2002
}

\section{Mafalda Blanc}

No passado dia 14 de Outubro viu-se o Departamento de Filosofia subitamente confrontado com a chocante notícia do falecimento do Professor João Paisana. Não quis, por isso, deixar passar a ocasião da abertura oficial de mais um ano de actividade lectiva sem the prestar uma primeira homenagem, expressando o sentimento colectivo de profunda mágoa e gratidão por mais de trinta anos de dedicada e preciosa colaboração.

O serviço que vinha prestando como docente e investigador à Faculdade de Letras da Universidade de Lisboa, onde aliás estudou e acabaria por se doutorar, o seu contributo inestimável para o desenvolvimento dos estudos filosóficos em Portugal fizeram com que o seu desaparecimento nos deixasse a todos - colegas, funcionários e estudantes - a braços com uma situação de vazio e de perda irreparáveis.

É que não foi apenas o filósofo rigoroso e empenhado, o promotor incansável da Fenomenologia e das Filosofias existencial e hermenêutica que nos faltou, méritos que the eram reconhecidos pelas suas funções como presidente da Associação Portuguesa de Filosofia Fenomenológica, director da revista "Phainomenon" do Centro de Filosofia da Universidade de Lisboa e coordenador do Mestrado em Fenomenologia e Hermenêutica - foi também o homem, camarada e amigo incondicional, que a todos acolhia sem favor ou distinção, e gratificava com atenção e generosidade ilimitadas.

O que ficou por cumprir na sua carreira de pensador e de que muito havia, justificadamente, que esperar - João Paisana vinha já há algum tempo preparando uma obra nos domínios da filosofia da comunicação e da ética -, assim como o diálogo, agora cruelmente interrompido, que vinha mantendo, de um modo ou de outro, com todos os que sentia empenhados numa comum vocação de pensar obrigam a que hoje, em uníssono com toda a comunidade filosófica portuguesa, nos sintamos um pouco mais pobres, desamparados e órfãos na tarefa que é a nossa, como Departamento de Filosofia, de passar testemunho às novas gerações, prosseguindo o mesmo intento de exigente reflexão e questionação.

Que me seja permitido evocar, ainda que a breve trecho e na minha qualidade de colega, ex-aluna e amiga, o perfil do pensador, pedagogo e filantropo, que foi, para lá de tudo, João Paisana.

Se o interesse teorético, a exigência de uma cabal clarificação da experiência cognitiva o levaram da ciência à filosofia, foi no contacto com a obra de Husserl, nos seus anos de estudante em Lovaina, que acabaria por colher a orientação decisiva 
do seu pensar, já no que diz respeito ao entendimento da natureza e método da própria filosofia.

$\mathrm{Na}$ verdade, num primeiro momento, a fenomenologia explicitativa de Husserl fornecer-lhe-ia, com o primado reflexivo do cogito intencional e o seu método intuitivo e descritivo de abordagem da experiência pré-predicativa, não só alternativa credível a todo o tipo de naturalismo, como um instrumento de investigação promissor, mais consentâneo com a natureza da filosofia que o construtivismo lógico da filosofia post-kanteana.

De regresso a Lisboa, na sua passagem como estudante pela Faculdade de Letras, deu-se certamente João Paisana conta, em contacto com o Kantismo e o Idealismo alemão, do primado do "eu" prático e histórico sobre o sujeito cognitivo, preparando-se desse modo para a recepção calorosa das teses de "Ser e Tempo" de Heidegger e sua adopção, de preferência ao idealismo gnoseológico de Husserl.

$\mathrm{O}$ confronto entre as duas fenomenologias - a explicitativa, de Husserl, e a hermenêutica, de Heidegger - constitui o tema do seu Doutoramento, publicado em 1992 sob o título "Fenomenologia e Hermenêutica", que viria a tornar-se referência obrigatória para todo o investigador do sector.

A estrutura enquanto que (Als-Struktur) hermenêutica, de carácter pré-objectivo, relevada por Heidegger como constitutiva do significar originário da existência (Existenz) e fundamento da verdade predicativa, afigura-se, doravante, a Paisana como o verdadeiro ponto de Arquimedes da filosofia, o núcleo originário de elaboração discursiva de toda a genuína compreensão do ser, a que deve reportar-se toda a análise ontológica. Determina-se então esta, não já como uma investigação formal ou categorial das estruturas constitutivas do objecto em geral, à maneira de Husserl ou de Hartmann, mas como uma elucidação do sentido modal e temporal do próprio ser (Sein selbst), para que acaba por remeter toda a fenomenalidade.

$\mathrm{Na}$ linha da Ontologia fundamental (Fundamentale Ontologie) do primeiro Heidegger, designadamente dos "Grundprobleme der Phänomenologie", compreende então Paisana a fenomenologia, enquanto método da Ontologia, como uma exegese. do sentido do ser (Sinn des Seins), levada a cabo através de três procedimentos essenciais: a redução (Reduktion) do ente ao ser, a destruição (Destruktion) da tradição, e a construção (Konstruktion) de possíveis modos de ser-no-mundo.

Um tal entendimento do filosofar como tarefa hermenêutica de construção histórica e comunitária da verdade marca o essencial da orientação filosófica posterior do pensador, numa linha que, apesar da matriz heideggeriana, não deixará de integrar com pertinência as contribuições de um Gadamer, Habermas, Apel ou Austin para a compreensão das dimensões comunicativa, social e histórica do significar. É o que os estudos reunidos no livro "História da Filosofia e Tradição Filosófica", de 1993, e o artigo "Experiência e Comunicação", de 2000, nos permitem verificar em profundidade - aquele último constituindo, com clareza e rigor exemplares, uma súmula de toda a sua reflexão.

Um suposto, jamais contestado, rege e norteia, a nosso ver, a filosofia de João Paisana. Trata-se do primado do questionar, entendido como abertura de possibilidades no mundo histórico, sobre todo o modo ôntico de ser-no-mundo, em que o homem se encontre lançado e pelo qual seja determinado. Tal primazia do possivel sobre o real e o dado, pela qual o ser-aí existente não tem um modo de ser ôntico fundante, nem a Ontologia um objecto material, funda-se na orientação futurizante da temporalidade humana, que inclui, na tensão para o nada que a caracteriza como poder-ser finito, qualquer modo possível de significar a existência.

Desta forma, apesar de já sempre ter respondido existencialmente à questão do sentido do seu ser pela via da tradição em que se encontra e que já sempre o 
sobredetermina a uma compreensão pré-ontológica, não deixa o homem, por isso, individual e colectivamente, de ter o poder e o dever de proceder ao exame crítico do valor de verdade de tal resposta, interpretando-a, à luz do questionar, como uma possibilidade fáctica de existir entre outras, cuja pretensão à verdade e preferencialidade requer adequada legitimação, através do confronto e livre discussão com outras concepções do mundo igualmente válidas.

$\mathrm{O}$ artigo, acima citado, da revista "Phainomenon" dá-nos conta da crescente proximidade de Paisana às teses da hermenêutica crítica e comunicacional de J. Habermas, a sua adesão a um conceito de racionalidade comunicacional, assente na discussão e argumentação, como condição de uma sociedade livre, emancipada e baseada em relações de simetria e paridade.

A pedagogia de João Paisana, o seu modo de estar na vida e na Academia decorrem desta sua filosofia, animada por um ideal de transparência e de comunicação ilimitadas. A sua convicção no poder auto-reflexivo e crítico da linguagem, assim como no seu potencial de consensualidade, enquanto esquema e jogo de interacção social, levava-o a privilegiar, em qualquer situação, o diálogo e a discussão, preferindo, à transmissão sempre impositiva de conteúdos, o direito à questão e a troca de perspectivas numa partilhada exigência de explicitação e de fundamentação.

No quadro que traçámos e ém que prepondera um ideal autonómico de reflexividade integral, não há lugar para a atestação de uma Verdade transcendente, anterior às iniciativas por que a consciência se lança na projecção e construção do sentido. É que nada, a ver do nosso pensador, deve anteceder a liberdade, nem mesmo a facticidade, por que o homem já sempre se encontra entregue à tarefa de se pôr e fazer como humanidade.

Face a um tal idealismo, de matriz sartriana, compreende-se que Paisana não pudesse acolher favoravelmente a inflexão da Fenomenologia no sentido de uma Ontologia ou até mesmo de uma Filosofia Primeira, para que apontam os trabalhos de um Heidegger e do último Merleau-Ponty. Com efeito, à sua luz já não se afirma o ser passível de uma abordagem voluntarista e construtivista, antes se dando a pensar numa insigne experiência de afecção e destinação que, indo ao encontro de cada um, o leva até onde pode ir na sua relação com a verdade. Para Paisana, porém, é sempre o homem que, intersubjectivamente embora, estatui as condições do aparecer, numa certa lógica produtiva da verdade, que tem no horizonte ocultante-desocultante da tradição a instância mediadora do seu próprio constituir significativo.

Quaisquer que fossem, no entanto, as posições que sustentasse na abordagem dos temas e questões da filosofia, a exemplaridade da forma com que sempre protagonizava o pensar numa postura de exigência e rigor, a sua abertura ao diálogo e prontidão para acolher quem o solicitasse, aliadas a uma gentileza e cavalheirismo sem par, fazem com que hoje lamentemos, na perda do filósofo promissor, a do colega, professor e amigo insubstituíveis.

Faculdade de Letras de Lisboa, 30 de Outubro 2001 
